Fikrah: Jurnal Ilmu Aqidah dan Studi Keagamaan

issn 2354-6147 eissn 2476-9649

journal.stainkudus.ac.id/index.php/fikrah

DOI: http://dx.doi.org/10.21043/fikrah.v7i1. 4801

Volume 7 (1) 2019, 155-166

\title{
Quran Apps in Playstore: The Problem of Authentication and Religious Authority
}

\author{
Lina Kushidayati $1^{*}$ \\ 1 Mahasiswa Pascasarjana UIN Walisongo Semarang, Indonesia \\ *linakushidayati@gmail.com
}

\begin{abstract}
Abstrak
Artikel ini membahas tentang aplikasi di Google Play Store yang muncul seiring dengan maraknya penggunaan smartphone. Hal ini juga berpengaruh pada pola hidup umat Islam termasuk dalam praktik beragama, sebagai contoh dalam membaca Quran. Banyak aplikasi Quran yang tersedia di Play store dan memunculkan pertanyaan tentang otoritas keagamaan karena siapa saja yang bisa mengunggah aplikasi Quran berbasis android di Play store. Hasilnya menunjukkan bahwa perkembangan aplikasi Quran digital memunculkan gaya baru dalam beribadah seperti membaca Quran.
\end{abstract}

Kata kunci: Aplikasi Islami, Play store, otoritas keagamaan, masalah autentisitas

\begin{abstract}
This article discuss about an application at Google Play Store that appears along with the rise of smartphone usage. It's also take effect to Muslims live style and religious practice, for example in reading Quran. There are many Quran applications are available on the Play store, its raises questions on religious authorities because anyone can upload an Androidbased Quran application on the Play store. A descriptive qualitative approach use to analyze Qur'an apps in Google Play store. The apps are chosen based on the numbers of download and comments from the users. The results show that the growth of digital Quran applications raises new styles of worship such as reading the Quran on smarthphone application.
\end{abstract}

Keywords: Islamic app, Play store, religious authority, authentication problem. 


\section{Introduction}

Islam is a religion which disseminated through oral and written tradition. The current Islamic values also disseminated in digital form along with oral and writings traditions. Both formal and non-formal Islamic educational institutions focus on training people who memorize al-Qur' an. Other educational institutions teach their students to create a beautiful Qur'anic writing in addition to the study of fiqh, hadith and other Islamic literature. All of the materials are available in print. Thus, basically, Muslims are not disturbed should the digital world or the internet is disrupted. There are many people who memorize Qur'an and manuscripts and printed books are accessible. Denying the existence of technology in the lives of Muslims is misleading (Hidayat, 2016). The development of technology goes hand in hand with its utilization and user's demands. The increasing number of applications and internet program, including mobile apps, intended for Muslims indicates Muslims' interest in technological development. Therefore, the study of those applications is necessary in order to understand Muslims attitude toward technology.

Al Qur'an is a sacred book from Allah revealed to the Prophet Muhammad. Its printed format, usually called Mushaf, is widely studied by Muslims. Currently, digital Islamic products are blooming, including Digital Qur'an Series. The Digital Qur'an run on special devices or special mobile device. Some of these products come with a translation in multi-languages, books of hadith' collections, prayer timings and Qibla direction. All of these features can be accessed through a single application which is very exciting for users. There are numbers of mobile Qur'an application accessible for Muslim for free from Google Play store. The purpose of this research is describing Qur'an apps Google Play Store and its relation to the issue of authenticity of the text.

The relations between the digital world and Islam has drawn the interest of researchers, Talib et al (2015) discusses the security vulnerability of Quran apps. The Mobile Quran apps developers should convey an assurance that the contents of their apps were credible, and even upon interaction with add-on features, would not jeopardize content validity. A study conducted among college students in Saudi Arabia shows that despite the students living in a strict Islamic society, they still see themselves as a part of the connected world. Apparently, there is a positive relationship between students attitudes toward learning through educational video (Ezzi, Teal, \& Izzo, 2014). 
The rapid growing mobile apps can also be used for education purposes. Research about mobile apps "Say Quran" and its relations to the process of learning Quran among students shows there is a positive relationship between mobile app 'Say Quran' and students' perceived performance, satisfaction and behavior while engaged in studying the Holy Quran (Alqahtani \& Mohammad, 2015).

\section{A Mobile Application Overview}

Mobile applications are consisting of software/set of program that runs on a mobile device and perform certain tasks for the user. It is a new and fast developing section of information and communication technology. The mobile application usually is easy, user-friendly, inexpensive, downloadable and run-able in most of the smartphone either on the entry level of high-end phone. The mobile application has wide uses for its vast functioning area like calling, messaging, browsing, chatting, social network communication, audio, game, and so forth. Some mobile applications are pre-install in the phone while others can be downloaded from the internet and installed in the mobile phone by users(Islam, Islam, \& Mazumder, 2010).

The numbers of a mobile application or mobile apps are largely developed for various mobile platforms. By the end of July 2013, a survey study showed that there were more than 1.9 million mobile apps and more than 100 billion cumulative downloads at Apple's App Store and Google Play store. Apparently, there is no research output on the general consensus of the classification of mobile apps, even though building mobile apps in any situation falls within the generic software development life cycle (SDLC) (Talib et al., 2015). According to application area, mobile apps can be classified into six categories: communications, games, multimedia, productivity, travel, and utilities (Islam et al., 2010).

\section{Android Operating System}

Android is a comprehensive open source platform designed for mobile devices supported by Google. It is a Linux-based operating system mainly used for running mobile devices such as smartphones and tablet computers. However, due to its open and customizable features, Android is applied in a wide range of electronic devices such as laptops, smart TV, cameras, headphones, wristwatches, game consoles, car CD and DVD players, home automation and others. Unlike other proprietary operating systems such as iOS, Blackberry OS or Windows OS which 
are licensed and controlled by certain companies, Android OS is independent and runs on devices from different vendors. As of May 2013, Android dominates the smartphone market accounting $74.4 \%$ of worldwide smartphone sales. Android is a full-fledged operating system and a complete software stack for mobile devices. Android APIs are a rich set of system services wrapped in an intuitive class file which provides easy access to several features like location, web, telephony, Wi-Fi, media, camera, and so on. All the tools, frameworks and software necessary to develop a mobile application are available for free (Poudel, 2013).

\section{Method}

This article uses a descriptive qualitative approach to analyze Qur'an apps in Google Play store. The apps are chosen based on the numbers of download and comments from the users. Some of those apps have been downloaded by more than 10 million times. In this research, I simply follow the top list provided by Google Play store based on the numbers of download.

\section{Religious Authority}

The statements from 'authorities' on the Islamic legitimacy (or not) of the Internet often cannot be separated from political strategies, often articulated utilizing religious 'values' and concepts, which have sought to engineer specific forms of what are described as Cyber Islamic Environments (Akbar, 2013; Alwi, Ibrahim, Anas, \& Yaacob, 2014; Thandayath, 2016). This refers to a variety of contexts, perspectives and applications of the media by those who define themselves as Muslims The evolution of using the Internet as an 'Islamic tool' has been observed in a relatively compressed historical period, and it may be only with the passage of time for an appropriate perspective for the full picture to be realized. One significant issue for future research in this area is that little has been archived or recorded to date, and that sites emerge and disappear with regularity. Despite 'digital divide', the internet is sufficiently relevant to be the focus of study, particularly in relation to how political and religious concepts are discussed, depicted and 'exported' to a (potential) global audience. 'Digital divide' or diversity of usage and patterns of access are influenced by a number of regional and cultural factors, such as: the cost using of the internet, individual awareness, education, relationship between the government, ISPs and telecommunications service providers (Bunt, 2003). 
New media technologies support significant community debates about gender politics, international security, and the Qur'anic interpretation. Some scholars argue that for every new information technology, a battle over the presentation and interpretation of Islamic texts follows. There are approximately 141 million Muslims are online across 75 countries where Muslim are known to be a majority (no less than 50 percent of the population) or a sizable minority (10 percent minimum). It means about 10 percent of the global Muslim population is online. This is a considerable number, since there is evidence that internet access in developing Muslim countries is not only a personal, home, or work-based information service for wealthy elites. A much larger-and difficult to assaypopulation uses public internet access points such as cybercafés or libraries (Howard, 2011).

In many years, governments in Muslim countries, as other developing world, have been encouraged to reform their telecommunications sector through four primary reforms. Firstly, they are urged to privatize the national telecommunications provider. It means a government would sell its majority stake in the public information infrastructure in order to change the mission from national service to investor profits. Secondly, the governments are advised to legally separating the agency that regulates the telecommunications sector from both the service provider and the executive branch of government. In another word, the government would transfer public oversight from politicians to technical expert. Thirdly, many governments are pressured to meaningfully depoliticize their telecommunications agency by leaving appointments and decisions to technology experts. The last, the governments have been encouraged to liberalize the markets for consumer electronics and communications provider and allowing competition between firms. These four are the most commonly chosen and the most often promoted by multilateral lending agencies (Howard, 2011).

As a religion, Islam would function effectively without the Internet. However, some minority Muslims and Islamic organizations would be bereft of their significant propagation and networking tool, unable to dialogue, research and disseminate their message to followers or to interested (Muslim and other) observers. This due to the shackles of state censorship, unable to access other forms of media, and restricted in the forms of local and global contact and dialogue facilitated through the Internet. In such situation, the Internet is in fact a window into aspect of the 'Muslim world' and consciousness. The proliferation of Islamic 
websites, chat rooms, e-mail lists and other related media activity - including expressions of beliefs and the articulation of agendas - was a phenomenon heralding a maturity of Cyber Islamic Environments. Thus, the extensive application of the Internet as a means of projecting Muslim authority and disseminating religious opinions represents a long-term and technological notions of power, wrapped up in a 56k modem and sent in digital packets on uncharted and twisted routes across the world (Bunt, 2003).

Anderson and Gonzalez-Quijano (2006) describe tri-phased history of Islamic media in the era of Internet. At the time that Internet was formed, students from Muslim countries who were studied at leading Western universities or research institutes and other diaspora Muslims are engaged on line in discussions of how to apply Muslim rules and interpretations to conditions of modern life in non-Muslim majority societies that lacked many familiar reference points, extended family live and public institutions. The discussions were characterized by an absence of contributions from ulama, and the participants did not show much training in religious hermeneutics. This early online discussion of Islam is a widely ranging character that attracted the attention of more conventional spokespersons of official Islam and of oppositional or militant voices as the Internet became more public. The second phase is giving way to a more modulated one, orthodox in theology, and mainstream in interpretation but more dynamically attuned to developing an audience or public on line. Their work or leisure bring those Muslims on line for news and information that they extend to finding an Islam that is expressively and in its focus attuned to their interests, problems, resources, and practices of information seeking. This may include fatwas and also of advice of a more social and psychological sort, material for religious instruction of children as well as formal sermons, news with a Muslim interest and other kinds of religious commentary on current issues (Anderson \& Gonzalez-Quijano, 2006).

Many sociologists of religion contend that the Internet Age has brought about a crisis of religious authority. Institutionalized authorities are in crisis as cyberspace has inevitably brought about a democratization of knowledge with contesting centers of influence. This new media are more participatory, less personalized messages bound to particular context. In another word, there is a redrawing of the relational line between authority and community (Han and Nasir 2015). 
Over the centuries, the issue of qualification and authority has occupied Muslim contexts. The discussion on the nature of authority and decision-making process in Islam dates back to the time of the Prophet Muhammad. Islamic written sources range from the Qur'an to vast collection of hadith and sunna, sources based on oral transmission which were subsequently assembled, analyzed and systemized within various written collection. These works have in turn informed the training of various Muslim authorities throughout the generation, and in contemporary contexts their influence is felt in sermons, academic discourse, dialogue and diverse media. An understanding of ijitihad (a term associated with a striving for the pragmatic interpretation of Islamic primary sources in the light of contemporary condition) has been a key to examining in detail the processes associated with decision-making. The word ijtihad similar in meaning with 'renewal', 'reform', 're-evaluate', and 're-alignment'. These terms have several levels of meaning and relevance, depending on context. There are diversity understanding of who is entitled to apply ijtihad, whether, an 'appropriately qualified' mujtahid is required, and if the decision is binding on individuals, a community or the Islamic world (Bunt, 2003).

\section{The Qur'an Apps}

In the digital era, there is no border between author and readers. This is also in the case of religion where $d a^{\prime} i$ and madh'u both are the users of the digital media. As users, both are acting as producers, consumers as well as distributors of information. Thus the authority is no longer in the hand of $d a^{\prime} i$, since madh'u who used to be the objects of $d a^{\prime} w a$ are now share the similar opportunity to produce and reproduce the message of Islam and then share or re-share it to others. In a digitally connected society, whenever a person received a religious message, he/she usually has a strong intention to forward it to family, friends, and relatives. Thus a person may produce/reproduce religious message even though he/she is not a da'i (Aripudin, 2011).

Google Play store provide a space for public to develop an application in any field and then share it to everyone. Some apps are absolutely free of charge while others are free with certain limitation or in-app purchase. Developers of apps in Google Play store can be anybody from any background. There are apps develop by government, company, university or legal institutions while other apps are developed by an individual. Apps developed by a formal and legal institution 
usually are expected to be more reliable but who should guarantee the reliability of apps developed by an individual?

The Qur'an apps in Google Play store are varied. Some are focus on the text and translation while other developers are providing supplementary features such as murattal, kiblah finder, praying schedule, or the books of hadith. Business' orientation of the developers is also varied. There are developers providing qur'an apps free of charge while other encourage donation for the sustainability of the app (table 1). Some other provides the app for free but there are ads at the bottom of the page (table 2). User may upgrade the app for some amount of money to remove the commercial. The other apps are free of charge for the regular version, but user should purchase for additional features. The amount of money for additional features is varied from Rp. 2000 up to Rp. 5 million (table 3).

Tabel 1 Free or charge Qur'an Apps in Google Play Store

\begin{tabular}{llllll}
\hline No & Name & Developer & Features & Type & Authorization \\
\hline 1 & Al-Quran al-Hadi & Pusat Kajian Hadis & Translation & Free, no ads & $\begin{array}{l}\text { Text of al- } \\
\text { Quran is taken } \\
\text { from } \\
\text { quran.com }\end{array}$ \\
& Qur'an Kemenag & MORA & Tashih from \\
& Al-Quran (tafsir and \\
by word) & $\begin{array}{l}\text { Greentech app } \\
\text { foundation, UK }\end{array}$ & $\begin{array}{l}\text { Translation, tafsir, } \\
\text { Turattal } \\
\text { word translation }\end{array}$ & $\begin{array}{l}\text { Free, no ads } \\
\text { users are } \\
\text { encouraged to } \\
\text { donate } \\
\text { Free, no ads, }\end{array}$ & $\begin{array}{l}\text { Not } \\
\text { mentioned }\end{array}$ \\
& $\begin{array}{l}\text { AlQuran Tanpa } \\
\text { internet }\end{array}$ & Muhamed Hussien & Colorful tajwid & $\begin{array}{l}\text { Not } \\
\text { mentioned }\end{array}$ \\
\hline
\end{tabular}

Tabel 2 Free Qur'an Apps with ads

\begin{tabular}{|c|c|c|c|c|c|}
\hline No & Name & Developer & Features & Type & Authorization \\
\hline 1 & $\begin{array}{l}\text { Al Quran MP3 } \\
\text { (Full Offline) }\end{array}$ & SY Media & $\begin{array}{l}\text { Full Offline, } \\
\text { Wallpaper, Listen in } \\
\text { background, Murottal }\end{array}$ & Contain ads & Not mentioned \\
\hline 2 & $\begin{array}{l}\text { Al Quran MP3 } \\
\text { Full Offline }\end{array}$ & andromoapp & $\begin{array}{l}\text { Full Offline, listen in } \\
\text { background }\end{array}$ & Contain ads & Not mentioned \\
\hline 3 & $\begin{array}{l}\text { Al Sudais Full } \\
\text { Quran Offline }\end{array}$ & $\begin{array}{l}\text { KareemTKB, } \\
\text { Egypt }\end{array}$ & Listen in background & Contain ads & Not mentioned \\
\hline 4 & Al Quran & Almubin.com & $\begin{array}{l}\text { Terjemah bahasa } \\
\text { Inggris, teks latin, } \\
\text { Audio Mp3 }\end{array}$ & Contain ads & Not mentioned \\
\hline 5 & $\begin{array}{l}\text { Al-Quran \& } \\
\text { Terjemahan } \\
\text { Indonesia }\end{array}$ & Guruandroid & $\begin{array}{l}\text { Terjemah, audio Mp3, } \\
\text { prayer schedule, } 99 \\
\text { names }\end{array}$ & Contain ads & Not mentioned \\
\hline 6 & $\begin{array}{l}\text { Al-Quran Offline } \\
\text { Baca }\end{array}$ & $\begin{array}{l}\text { Khasologix, } \\
\text { Islamabad }\end{array}$ & Surah Index & Contain ads & Not mentioned \\
\hline 7 & Al-Quran & $\begin{array}{l}\text { Deenekhalis, } \\
\text { Islamabad }\end{array}$ & Surah index & Contain ads & Not mentioned \\
\hline 8 & Al-Quran Kareem & HIJRAH Insani, & Texts in PDF, & Contain ads & Not mentioned \\
\hline
\end{tabular}


Quran Apps in Play Store...

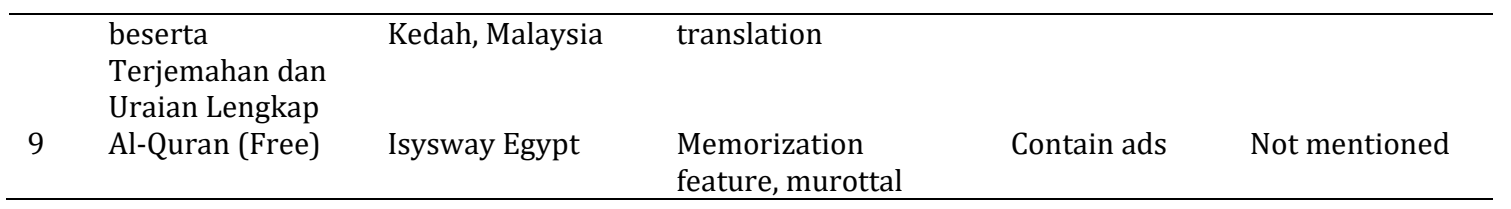

Tabel 3 In-app purchase Qur'an Apps in Google Play Store

\begin{tabular}{|c|c|c|c|c|c|}
\hline No & Name & Developer & Additional Features & Type & Authorization \\
\hline 1 & $\begin{array}{l}\text { Al-Quran } \\
\text { Indonesia }\end{array}$ & $\begin{array}{l}\text { Andi Unpam } \\
\text { (Tangerang } \\
\text { Selatan) }\end{array}$ & $\begin{array}{l}\text { Audio murottal, } \\
\text { Islamic calendar, } \\
\text { praying schedule, } \\
\text { qibla findert, share } \\
\text { ayat, tafsir al-Jalalain }\end{array}$ & $\begin{array}{l}\text { Contains ads, } \\
\text { in-app } \\
\text { purchases for } \\
\text { Rp. } \\
20,000 / \text { item }\end{array}$ & $\begin{array}{l}\text { The translation } \\
\text { in taken from } \\
\text { MORA but there } \\
\text { is no statement } \\
\text { concerning } \\
\text { tashih }\end{array}$ \\
\hline 2 & $\begin{array}{l}\text { My Quran Al } \\
\text { Quran dan } \\
\text { Terjemahan }\end{array}$ & The WALi studio & $\begin{array}{l}\text { Audio murottal, } \\
\text { praying schedule, } \\
\text { translation from } \\
\text { MORA, tafsir al } \\
\text { Jalalain, word to } \\
\text { word translation }\end{array}$ & $\begin{array}{l}\text { Contain ads, } \\
\text { in-app } \\
\text { purchases for } \\
\text { Rp. } 4,300 \text { up to } \\
\text { Rp. } \\
5,000,000 / \text { item }\end{array}$ & Tashih by MORA \\
\hline 3 & $\begin{array}{l}\text { Al Quran Perkata } \\
\text { dan Tafsir }\end{array}$ & Muslim Dev & $\begin{array}{l}\text { Praying schedule, } \\
\text { qibla finder, Arab } \\
\text { dictionary, hadith, } \\
\text { doa mustajab, } \\
\text { asbabun nuzul }\end{array}$ & $\begin{array}{l}\text { Contain ads, } \\
\text { in-app } \\
\text { purchases }\end{array}$ & $\begin{array}{l}\text { Texts al-Quran } \\
\text { and tafsir are } \\
\text { taken from } \\
\text { quran.kemenag }\end{array}$ \\
\hline 4 & Muslim Pro & $\begin{array}{l}\text { Muslim Pro } \\
\text { Singapore }\end{array}$ & $\begin{array}{l}\text { Praying schedule, } \\
\text { kiblah finder, iftar } \\
\text { schedule, tajwid, } \\
\text { digital tasbih, } \\
\text { community, halal } \\
\text { restaurant and } \\
\text { mosque finder, do'a }\end{array}$ & $\begin{array}{l}\text { Contain ads, } \\
\text { in-app } \\
\text { purchases } \\
\text { Rp.7,000-Rp. } \\
389,000\end{array}$ & Not mentioned \\
\hline 5 & $\begin{array}{l}\text { Al Quran Bahasa } \\
\text { Indonesia }\end{array}$ & $\begin{array}{l}\text { Seconda Variante, } \\
\text { Spain }\end{array}$ & $\begin{array}{l}\text { Tajwid, downloading } \\
\text { audio murottal }\end{array}$ & $\begin{array}{l}\text { Contain ads, in- } \\
\text { app purchases }\end{array}$ & Not mentioned \\
\hline 6 & $\begin{array}{l}\text { Al-Quran audio } \\
\text { lengkap }\end{array}$ & Muvi studio & Listen in background & Temporary free & Not mentioned \\
\hline 7 & Quran Kareem & $\begin{array}{l}\text { Islamicworld, } \\
\text { Rawalpindi }\end{array}$ & $\begin{array}{l}\text { Translation in } 19 \\
\text { languages, }\end{array}$ & $\begin{array}{l}\text { In-app } \\
\text { purchase } \\
\text { Rp.25.000/item }\end{array}$ & Not mentioned \\
\hline
\end{tabular}

\section{Tashih and Ads: the Problem of Authentication}

Tabel shows the diversity of developers of Quran apps in Google Play store. Those apps are among the most popular quran apps in Play store. Some developers provide translation in Indonesian however the developers seem to have different preference in choosing the sources of text of Quran and its translation. There is developer taking Quran text from others, such as al-Quran al-Hadi takes Quran text from quran.com while Al Quran Perkata dan Tafsir copying Quran text from quran.kemenag. However, as seen in table 1, 2 and 3, most of the developers do not mention the source of text and translation of Quran. Thus, the users are not given 
clear information about the apps and should there is some mistake in the text or translation, users may be not aware of it.

The Ministry of Religious Affairs (MORA) has a special department certifying the quality the text of Quran namely Lajnah Pentashihan Mushaf alQuran. This department has the responsibility to check all publication of mushaf alQuran from any mistake. It does not merely checking the printed version of Qur'an but also recording, cassette, CD and other electronic and digital form of Qur'an, including smartphone apps. However, the development of new media and internet has provided a space for everyone to develop and publish Quran app without requesting tashih from the Lajnah. Some developers announce their address while others merely give their e-mail. Thus, it would be difficult to trace who are the people behind the program.

Another problem may arise from Quran apps is advertisement. Both table 2 and 3 show examples of Quran apps containing ads. The ads are usually at the bottom of the page and do not disturb the reading and reciting of Quran. What the matter is the advertisement itself. Among the ads is online shop which shows the picture of female underwear. Some users may find it inappropriate to see such picture at the bottom of the holy Quran. Although the ads appear only while the users are connected to the internet, the developers are responsible to check what kind of advertisement is appropriate to be accepted.

The third type of quran apps is those which provide a free version for the regular apps but the users should pay certain amount of money to upgrade to the professional version. Among the benefit for upgrading to the professional version is free of ads. Among those in-apps purchase version of Quran application also provide features can be bought by the users starting from Rp. 4.300 until Rp. 5 million. Some founders argue they need donations to support the team while other testifying that some of the money is used for social responsibility, such as for the poor and the orphanage. Unfortunately, public report of the donation is not provided.

\section{Conclusion}

Quranic apps available in Google Play store in an example how the development of new media influenced Muslims' life. Android apps introduce a new way of performing ibadah, reciting Quran, which is much more handy and accessible. However, those applications are facing challenges such as the question of text quality (tashih) and translation. Another problem is inappropriate 
advertisement appearing at the bottom of Quran apps whenever the users are online. 


\section{Bibliography}

Akbar, G. (2013). Metode Pembelajaran Al quran Melalui Media Online. Indonesian Jurnal on Networking and Security (IJNS), 2(1).

Alqahtani, M., \& Mohammad, H. (2015). Mobile Applications' Impact on Student Performance and Satisfaction. Tojdel The Online Journal of Distance Education and e-Learning., 14(4), 102-112.

Alwi, E. A. Z. E., Ibrahim, S., Anas, N., \& Yaacob, Z. (2014). Digital Quran Applications on Smart Phones and Tablets: A Study of the Foundation Programme Students. Asian Social Science, 10(15).

Anderson, J. W., \& Gonzalez-Quijano, Y. (2006). Technological Mediation and the Emergence of Transnational Muslim Publics. In A. Salvatore \& D. F. Eickelman (Ed.), Public Islam and the Common Good (hal. 53-74). Leiden \& Boston: BRILL.

Aripudin, A. (2011). Pengembangan Metode Dakwah. Jakarta: RajaGrafindo Persada.

Bunt, G. R. (2003). Islam In The Digital Age: E-Jihad, Online Fatwas and Cyber Islamic Environments. London \& Sterling, Virginia: Pluto Press.

Ezzi, S. W., Teal, E. J., \& Izzo, G. M. (2014). The influence of Islamic values on connected generation students in Saudi Arabia. Journal of International Business and Cultural Studies, 9, 1-19. https://doi.org/10.1016/j.emj.2014.04.002

Han, S., \& Na, K. M. (2015). Digital Culture and Religion in Asia.

Hidayat, S. (2016). Al-Qur'an Digital (Ragam, Permasalahan dan Masa Depan). MUKADDIMAH, 1(1).

Howard, P. N. (2011). The Digital Origins of Dictatorship and Democracy. Oxford: Oxford University Press.

Islam, R., Islam, M. R., \& Mazumder, T. A. (2010). Mobile Application and Its Global Impact, (6), 72-78.

Munawar, B. (2001). Islam Pluralis, Wacana Kesetaraan Kaum Beriman. Jakarta: Paramadina.

Poudel, A. (2013). Mobile Application Development for Android. Turku University of Applied Sciences.

Talib, S., Mahmud, M., Abd Rahman, E. S., Suraya, A., \& Abubakar, A. (2015). Mobile Quran App Security Vulnerabilities. Proceedings of the 5th International Conference on Computing and Informatics, ICOCI 2015, (198), 447-455.

Thandayath, N. (2016). M Learning Apps as Information Source for Islamic Studies. Kelpro Bulletin, 20(2). 